\title{
EFFECT OF TILLAGE SYSTEM AND SOIL CONDITIONER APPLICATION ON SOYBEAN (GLYCINE MAX (L.) MERRILL.) AND ITS CROP MANAGEMENT ECONOMIC INDICATORS
}

\author{
LADISLAV KOVÁČ*, JANA JAKUBOVÁ, DANICA ŠARIKOVÁ
}

National Agricultural and Food Centre

KOVÁČ, L. - JAKUBOVÁ, J. - ŠARIKOVÁ, D.: Effect of tillage system and soil conditioner application on soybean (Glycine $\max$ (L.) Merrill.) and its crop management economic indicators. Agriculture (Pol'nohospodárstvo), vol. 60, 2014, no. 2, pp. 60-69.

Experiments with soybean on heavy soils of East Slovak Lowlands were established in the years 2010-2012. The effect of mineral fertilisers and soil conditioner application on soybean's yield using three tillage systems (minimum tillage (MT), conventional tillage (CT) and no tillage (NT)) was studied. Production costs and economic efficiency of crop management practices were evaluated. The influence of production year on soybean crop was significant in the order of 2011, 2010 and 2012. Statistical evaluation confirmed that the effects of CT and MT systems were more significant compared with NT system. No significant differences were found between the variants of the mineral fertiliser and conditioner application. Differences in the total cost of soybean cultivation, as measured between years, were not significant. Fertilisation variants with application of HUMAC agro and NPK generated the highest costs. On the other hand, the lowest costs were achieved at fertilisation variants with application of NPK alone. Comparing tillage variants, the CT system had the highest costs each year. Significant savings were achieved on MT and NT variants. During the experimental period, a profit was reached on all variants. Applying NPK alone, the highest profit was achieved in 2010 and 2012 using MT system and in 2011 with CT tillage. The variant $b_{2}$ with PRP sol in the years 2010 and 2011 was the most profitable using NT system and in 2012 using MT. Variant with HUMAC agro was the most profitable in each year using MT. The lowest income threshold for zero profitability was calculated in 2012. Using CT farming techniques at NPK fertilisation variant $b_{1}$ in 2012 , the income threshold was $1.85 \mathrm{t} / \mathrm{ha}$, at variant $\mathrm{b}_{2}$ PRP sol it was $2.10 \mathrm{t} / \mathrm{ha}$ and at variant $\mathrm{b}_{3}$ HUMAC agro it was $2.42 \mathrm{t} / \mathrm{ha}$. At MT and NT systems, the income threshold values for zero profitability were lower.

Key words: soybean, fertilisation, soil tillage, costs, economic effectiveness

Soybean cultivation requires suitable growing conditions. Yield and quality parameters of soybean are affected by many factors, but the appropriate interaction of soil and climatic factors that already exist at the regional level (Anthony et al. 2012), is essential.

Soybean, as reported by Šariková and Fecák (2007), is sensitive to incorrect and inconsistent essential tillage. Neglected and poorly made essential tillage makes stand establishment harder and increases the risk of its cultivation. Quality essential tillage is also an arrangement that can substantially eliminate the negative impact of such shortage and excess rainfall and reduces the variability of yields.

Conventional crop management (conventional tillage) requires a large number of operations that enormously increase the cost, but also cause soil compaction. Botta et al. (2007) based on their 3-year results of soybean in Argentina indicated that direct seeding reduces the number of crossings, which reduces fuel consumption by $35.5 \%$ and will be reflected in an increase in the yield of $29.2 \%$.

Soil conservations technologies in our country so far have been proven for maize, but in the USA and

Ing. Ladislav Kováč, PhD. (*Corresponding author), National Agricultural and Food Centre, Research Institute of Agroecology, 07101 Michalovce, Špitálska 1273, Slovak Republic. E-mail: kovac@minet.sk 
Canada these are successfully used in the cultivation of soybeans, especially in crop rotation with corn. Triplett and Dick (2007) indicated that direct sowing in the USA was already expanded in 1980 and after that the area grew in Australia, South America and Canada. Currently, these technologies are used here for about $23 \%$ of agricultural land. Direct seeding allows cultivation of a larger area with lower energy, labour and machinery consumption. Direct sowing directly affects crop, soil, hydrology and agricultural economy.

Archer and Reicosky (2008) report the farmers concerned about the use of direct seeding due to a potential risk of yield reduction and economic risks. Also, they face risks associated with the input costs, yields and the realisation prices. Their 7-year results show that the soybean affords achieving of higher economic benefits by minimising soil tillage and direct sowing against ploughing. Risk analysis showed that minimum tillage and non-tillage are a good alternative to conventional tillage.

Lança Rodríguez et al. (2009) verified different types of tillage in Brazil, including conventional tillage and direct seeding. There were no significant differences in yields using different tillage systems. Duseja and Dennis (2010) reached similar results in terms of the USA. For 7 years, they monitored soybean production indicators using conventional farming techniques and direct sowing. In the monitored period, they found significant difference only in 1 year regarding the benefit of direct sowing.

Experiments with soybean were established in conditions of heavy soils in Slovakia as well. The results showed that minimum tillage was better than direct sowing for the establishment of soybean crops (Fecák et al. 2009).

Level of the yield is not a decisive criterion (Katsvairo \& Cox 2000; Stanger et al. 2006) for selection of crop management. According to the authors, the dominant factor for the selection of technology is the economy of crop management. This is confirmed by their long-term studies with crops that included soybean also.

The aim of this study was to evaluate the parameters of soybean production, costs of production and the economic indicators using the three variants of fertilisation and the three variants of crop management on heavy soils.

\section{MATERIAL AND METHODS}

Field experiments with different soil cultivation were carried out between 2010 and 2012 at an experimental station in Milhostov, the unit of National Agriculture and Food Centre - Agroecology Research Institute Michalovce - on heavy Gleyic Fluvisol (WRB 2006) at an altitude of $101 \mathrm{~m}$. Gleyic Fluvisol in Milhostov is characterised as heavy, clay-loamy soil with average content of clay particles higher than 53\%. Gleyic Fluvisol was formed on heavy alluvial sediments during the long-time contact with groundwater and surface. The topsoil has a lump aggregate structure with high binding ability and has a weak perviousness through the whole profile. A layer of dark grey/yellow grey clay is situated at a depth of $0.7-0.8 \mathrm{~m}$ of soil profile. The agronomical properties of Gleyic Fluvisol are significantly influenced by the high content of clay particles. The experimental locality is characterised as a warm and very dry lowland continental climate region.

The study was realised in Milhostov, where the field stationary experiment was founded, using the appropriate crop rotation and Cardiff soybean variety. The spring barley was a fore crop for soybean in the rotation.

The experiment was conducted by randomised blocks in four replications. Experimental factors are described in Table 1. The size of an experimental plot was $276 \mathrm{~m}^{2}(6 \mathrm{~m} \times 46 \mathrm{~m})$ and the size of the whole experiment was $9936 \mathrm{~m}^{2}$.

"PRP sol" and "HUMAC agro" are soil amendments, which are applied to the soil to improve its properties, increasing soil fertility and consequently the yield of agricultural crops. PRP sol is a granular soil conditioner based on calcium and magnesium carbonates and technological additives (iron, zinc, boron, sodium, manganese, etc.). It contains $35 \%$ of calcium oxide and $8 \%$ of magnesium oxide. HUMAC agro is a granulated natural stimulator of soil fertility, high in humic acids (minimum $62 \%$ of dry matter). High content of humic acids and gradual release from the granules allow it to be applied only every $4-5$ years.

For all studied factors, yield of soybean was evaluated by mathematical and statistical methods. The multifactorial analysis of variance ANOVA 
from statistical package STATGRAPHICS, soybean yield and the factors was used (the year, tillage and application of fertilisers and conditioners).

The costs limits with reference to Kavka (2006) and Abrham et al. (2007) were used for cost evaluation of the set of machines and working procedures. They were recalculated for conditions of heavy soils of the East Slovak Lowland.

The variable costs consist of:

- Personal costs of drivers and workers (data obtained from Statistical Office of the Slovak Republic 2010, 2011);

- Costs of fuel, oils and lubricants were calculated from real prices of diesel fuel purchased for experimental workplace Milhostov, increased by $10 \%$ for consumed lubricants and oils;

- Repair and maintenance costs (with reference to Abrham et al. 2007);

- Material costs, calculated from the prices of seed, mineral fertilisers and pesticides in that year, purchased for experimental workplace Milhostov.
The fixed costs consist of:

- Fixed costs of energetic source and connected mechanisms (depreciations, taxes and fees, insurance, warehousing mechanisms, paid interest on capital) according to norms (Abrham et al. 2007).

The total production was calculated on base of real production for regional processor according to approved contract price.

Economic effectiveness of production technologies was evaluated in accordance with methodology proposed by Poláčková et al. (2010).

The calculation of economic effectiveness:

- Revenues $[€ / \mathrm{ha}]=$ yield $[\mathrm{t} / \mathrm{ha}] \times$ realisation price $[€ / \mathrm{t}]$;

- Profit/loss [€/ha] $=$ revenues [€/ha] - costs [€/ha];

- Profit/loss $[€ / t]=$ realisation price $[€ / t]-\operatorname{costs}[€ / t]$;

- Profitability of costs per 1 hectare [\%] = [profit/loss: costs] $\times 100$;

- Profitability of costs per 1 tone $[\%]=[$ profit/loss: costs] $\times 100$;

- Income threshold for zero profitability [t/ha] $=\operatorname{costs}[€ / \mathrm{ha}]$ : realisation price $[€ / \mathrm{t}]$.

$\mathrm{T}$ a

Experimental factors

\begin{tabular}{|c|c|c|c|c|c|c|c|}
\hline Factor & $\begin{array}{c}\text { Factor } \\
\text { level }\end{array}$ & Description & \multicolumn{5}{|c|}{ Tillage depth $[\mathrm{m}]$} \\
\hline \multirow{3}{*}{ A } & $a_{1}$ & $\begin{array}{l}\text { CT - (conventional tillage })- \text { stubble ploughing, } \\
\text { ploughing, smoothing, harrowing and sowing by } \\
\text { seeder Great Plains }\end{array}$ & \multicolumn{5}{|c|}{0.30} \\
\hline & $\mathrm{a}_{2}$ & $\begin{array}{l}\text { MT - (minimum tillage }) \text { - stubble ploughing by skive } \\
\text { cultivator, soil preparation by skive cultivator before } \\
\text { sowing and sowing by seeder Great Plains }\end{array}$ & \multicolumn{5}{|c|}{0.15} \\
\hline & $a_{3}$ & $\begin{array}{l}\text { NT - (direct sowing, no tillage })- \text { direct sowing } \\
\text { without ploughing by seeder Great Plains }\end{array}$ & & & 0 & & \\
\hline \multicolumn{3}{|c|}{ Fertilization doses $[\mathrm{kg} / \mathrm{ha}]$} & $\mathrm{N}$ & $\mathrm{P}$ & $\mathrm{K}$ & $\begin{array}{c}\text { PRP } \\
\text { sol }\end{array}$ & $\begin{array}{l}\text { HUMAC } \\
\text { agro }\end{array}$ \\
\hline \multirow{3}{*}{ B } & $\mathrm{b}_{1}$ & fertilization NPK & 30 & 13.08 & 24.90 & - & - \\
\hline & $b_{2}$ & fertilization N + conditioner „PRP sol“ & 30 & - & - & 200 & - \\
\hline & $\mathrm{b}_{3}$ & fertilization NPK + soil conditioner „HUMAC agro“ & 30 & 13.08 & 24.90 & - & 500 \\
\hline
\end{tabular}




\section{RESULTS AND DISCUSSION}

\section{Evaluation of grain production parameters}

Yield of soybean grains observed between 2010 and 2012 is shown in Table 2. Yield achieved in experiments greatly exceeded the yield achieved in agricultural practice (Rozborilová 2012). In the monitored period, the final yield was significantly affected by the year (the course of meteorological factors). Year 2011 statistically significantly affected the soybean crop compared with 2010 and 2012 (Table 3). In 2011, soya was seeded on $26^{\text {th }}$ of April (Figures 1,2). In this year, weather conditions were more favourable than in 2010 and 2012. Sufficient rainfall in June and July favourably impacted pro- duction of soybean, which was harvested on $22^{\text {nd }}$ of September. In 2010, soya was seeded on $27^{\text {th }}$ of April. A lower yield in 2010 resulted from a higher total rainfall after sowing in the month of May, which amounted to $219 \mathrm{~mm}$ that significantly exceeded long-term normal of May, which is $57 \mathrm{~mm}$. High rainfall and wet soil negatively influenced the initial development of soybean crop, which was reflected in the resulting yield. Rainfall above normal in August and September and temperatures lower than average delayed the ripening of soya, which was harvested on $6^{\text {th }}$ October. Compared with cultivation year 2010, 2012 influenced significantly less the final grain yield of soybean. Soya was seeded on $2^{\text {nd }}$ of May and the year 2012 was extremely dry and

T a b 1 e 2

Soybean seed yield in experimental years [t/ha]

\begin{tabular}{|c|c|c|c|c|c|c|c|c|c|}
\hline \multirow{2}{*}{ Factor } & \multicolumn{9}{|c|}{ Fertilisation } \\
\cline { 2 - 10 } & \multicolumn{3}{|c|}{$\mathrm{b}_{1}$} & \multicolumn{3}{c|}{$\mathrm{b}_{2}$} & \multicolumn{3}{c|}{$\mathrm{b}_{3}$} \\
\hline Tillage & $\mathrm{a}_{1}$ & $\mathrm{a}_{2}$ & $\mathrm{a}_{3}$ & $\mathrm{a}_{1}$ & $\mathrm{a}_{2}$ & $\mathrm{a}_{3}$ & $\mathrm{a}_{1}$ & $\mathrm{a}_{2}$ & $\mathrm{a}_{3}$ \\
\hline 2010 & 4.40 & 4.45 & 3.95 & 3.99 & 4.33 & 4.30 & 4.75 & 4.65 & 3.71 \\
2011 & 5.54 & 4.69 & 4.57 & 4.64 & 4.71 & 4.83 & 4.98 & 5.12 & 4.62 \\
2012 & 4.64 & 4.73 & 2.92 & 4.06 & 4.78 & 3.35 & 4.15 & 4.45 & 3.55 \\
\hline
\end{tabular}

Abbreviations see Table 1

$\mathrm{T}$ a

Multifactor analysis and multiple comparison test of monitored parameters of soybean seed

\begin{tabular}{|c|c|c|c|c|c|c|c|c|}
\hline \multicolumn{2}{|c|}{ Source of variation } & \multirow{2}{*}{$\begin{array}{c}\begin{array}{c}\text { Degree of } \\
\text { freedom }\end{array} \\
2\end{array}$} & \multirow{2}{*}{$\begin{array}{c}\text { F-value } \\
1.18\end{array}$} & \multirow{2}{*}{$\begin{array}{c}\text { P-value } \\
0.31\end{array}$} & \multirow{2}{*}{ 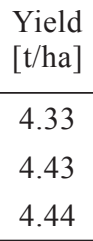 } & \multicolumn{3}{|c|}{$\begin{array}{l}\text { Homogeneous } \\
\text { groups }\end{array}$} \\
\hline Fertilization & $\begin{array}{c}\text { PRP sol } \\
\text { NPK } \\
\text { HUMAC agro }\end{array}$ & & & & & $\begin{array}{l}\mathrm{x} \\
\mathrm{x} \\
\mathrm{x}\end{array}$ & & \\
\hline Tillage & $\begin{array}{l}\text { NT } \\
\text { CT } \\
\text { MT }\end{array}$ & 2 & 44.47 & 0.00 & $\begin{array}{l}3.98 \\
4.57 \\
4.65\end{array}$ & $\mathrm{x}$ & $\begin{array}{l}\mathrm{x} \\
\mathrm{x}\end{array}$ & \\
\hline Year & $\begin{array}{l}2012 \\
2010 \\
2011\end{array}$ & 2 & 54.02 & 0.00 & $\begin{array}{l}4.07 \\
4.28 \\
4.86\end{array}$ & $\mathrm{x}$ & $\mathrm{x}$ & $\mathrm{x}$ \\
\hline $\begin{array}{l}\text { Residual } \\
\text { Total }\end{array}$ & & $\begin{array}{c}98 \\
102\end{array}$ & & & & & & \\
\hline
\end{tabular}

Abbreviations see Table 1 
warm as well. The average temperature during the growing season increased by $2.1^{\circ} \mathrm{C}$ compared with long-term normal and rainfall was lower by $41 \mathrm{~mm}$. The average yield in 2012 was lowest in the stud- ied years. In this year, soya was harvested on $13^{\text {th }}$ of September.

The lowest yields were achieved at variants of fertilisation $b_{1}$ (NPK) and $b_{3}$ (HUMAC agro) by

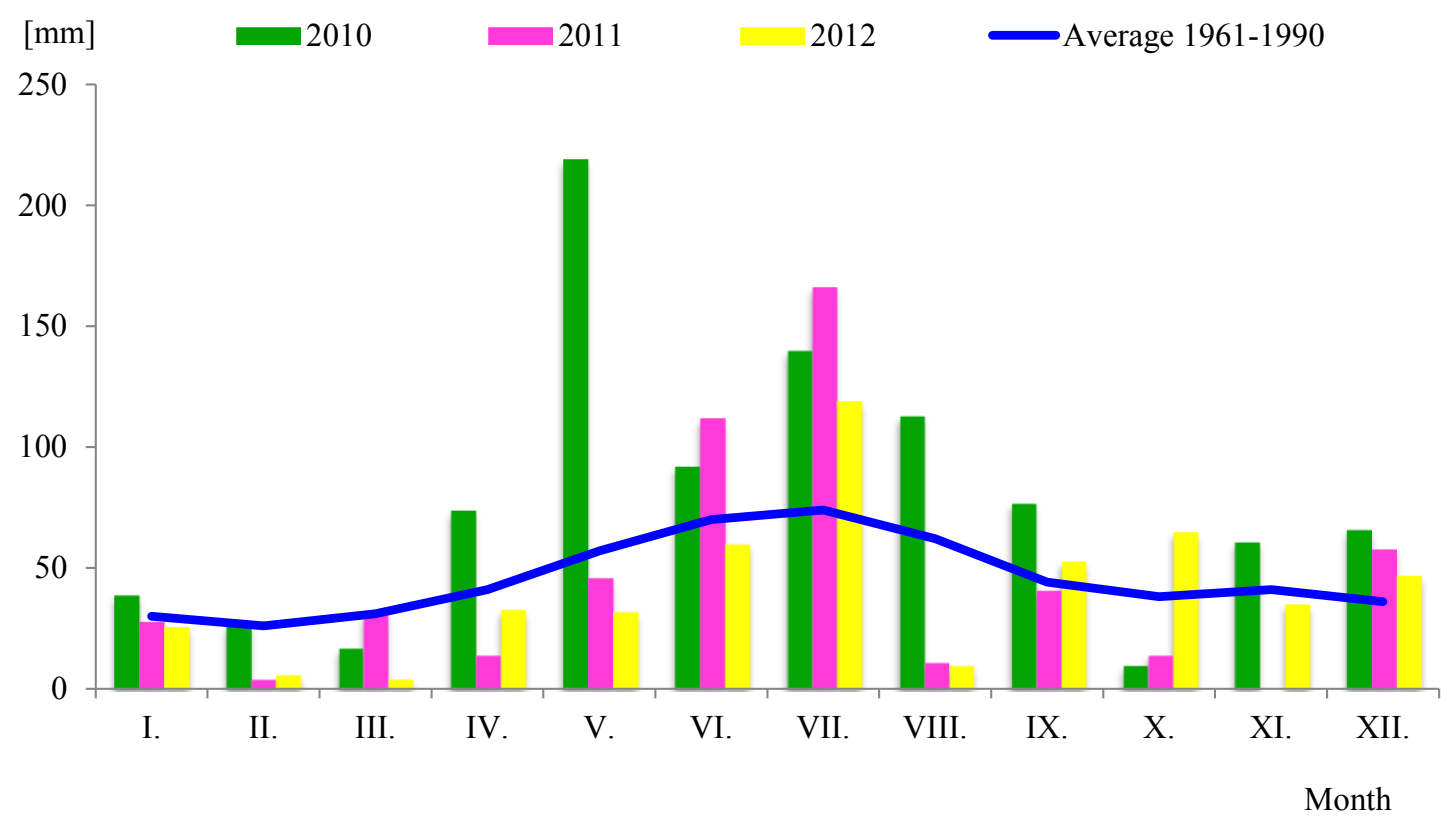

Figure 1. Rainfall for the years 2010-2012 and the long-term normal

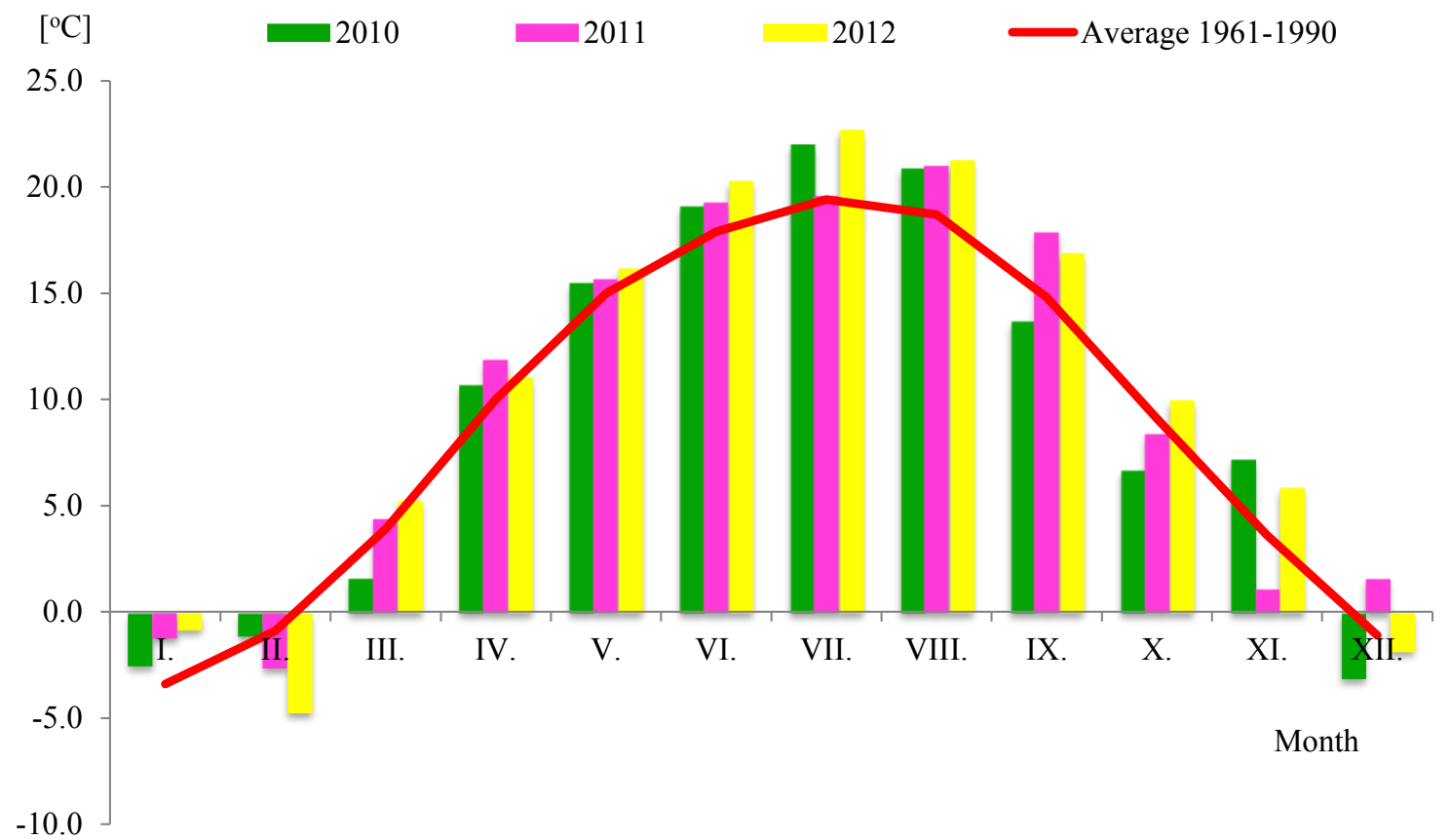

Figure 2. Temperatures for the years 2010-2012 and the long-term average 
direct sowing in each of the studied years. The lowest yield was at the variant $b_{2}$ (PRP sol) by direct sowing only in 2012. In 2011, in this fertilisation variant, the highest yield of $4.83 \mathrm{t} / \mathrm{ha}$ was achieved by direct sowing. The highest yield in the experiment (5.54 t/ha) was in 2011 using the conventional variant of tillage and the application of NPK (Table 2).

Statistical comparison of tillage technologies in the studied years confirmed that no-tillage technology has a non-significant effect on the soybean yield. Significantly, the yields were affected by conventional and minimum tillage. Similar results reached in experiments with soybeans on heavy soils between 2006 and 2008 (Fecák et al. 2010). These evaluations, however, do not correspond to the results given for soybean by Lança Rodríguez et al. (2009) and Duseja and Dennis (2010). The results of these authors indicate no signification in crop yields using different soybean cropping practices.

Statistical evaluation of the various applications of fertiliser and soil conditioner did not show a significant difference in yields between the different variants. Soil conditioners in the experiment did not significant influence the yield of soybean, but it is known to significantly affect the soil characteristics.
According to Šoltysová (2012), application of soil conditioner PRP sol allowed stabilising of soil reaction and increasing its average value. It worked to increase the humus and soil organic carbon content in the soil. Similar results have been reached by Balla et al. (2012) as well. As per Kotorová (2012), application of PRP sol promoters affected the physical properties of soil. It contributed to a reduction in density and an increase in total soil porosity. Tóth (2012) states that the product HUMAC agro is a soil improver carbon type and affects the improvement of soil structure, improving conditions for the development of micro-organisms, sorption and buffering capacity of the soil and so on.

\section{Assessment of costs for soybean planting}

Costs of soybean crop management in 2010 are shown in Figure 3. The highest costs were achieved at conventional tillage $a_{1}$ and using all three variants of fertilisation. At minimum tillage, the total cost compared with conventional technology was reduced by $€ 110.49 /$ ha and for direct sowing of $€ 128.30 / \mathrm{ha}$. Comparing variants of fertilisation, the lowest costs were determined for variant option $b_{1}$ (NPK fertiliser only). The fertilisation variant $b_{2}$ (PRP sol and N) costs were higher at $€ 91.98 /$ ha and

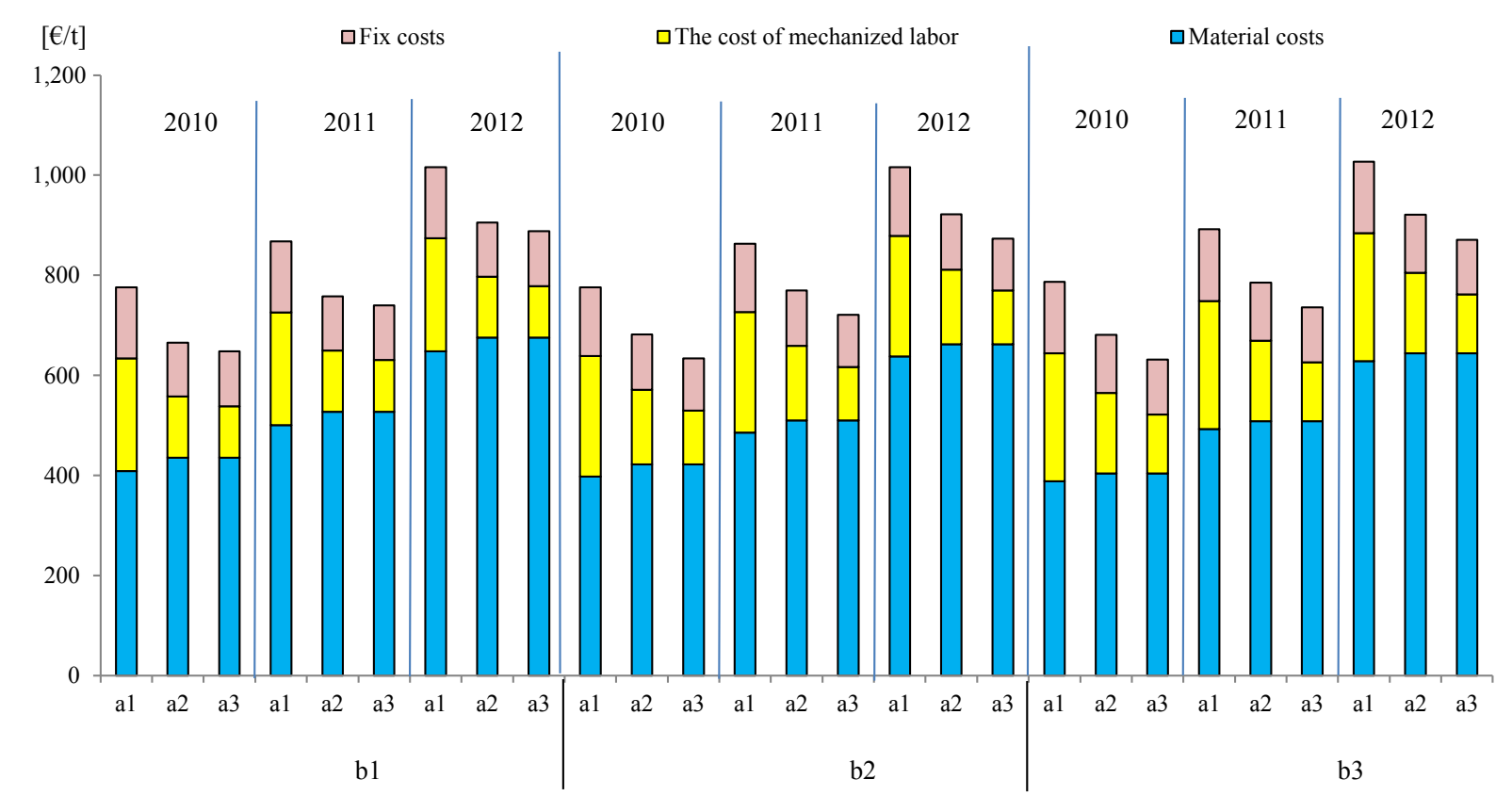

Figure 3. The costs of soybean cultivation in 2010-2012 - €/ha (Abbreviations see Table 1) 
the variant of fertilisation $b_{3}$ (HUMAC agro and NPK) $€ 240 /$ ha. More than $50 \%$ of costs in all experimental variants were material costs.

In 2011, due to lower prices of NPK fertiliser, material costs slightly decreased (by $€ 10.39-€ 17.52 / \mathrm{ha}$ ). This resulted in the total cost reduction on all variants except variant with minimum tillage $\left(a_{2}\right)$, where the total costs increase in the application of PRP sol $\left(b_{2}\right)$ for $€ 11.75 / \mathrm{ha}$ and in the application of NPK alone $\left(b_{1}\right)$ and HUMAC agro $\left(b_{3}\right)$ for $€ 16.21 /$ ha. The cost structure and the relationships between the different variants were analogous as in 2010 .

Costs of growing soybean in 2012 are shown in Figure 3. In 2012, compared with 2011, the cost of mechanised labour and fixed costs increased for all scenarios. With further decrease in prices of mineral fertilisers, material costs reduced for alternatives with NPK application alone $\left(b_{1}\right)$ and the application of HUMAC agro $\left(b_{3}\right)$. The increase in total cost was for all variants of conventional soil tillage $\left(a_{1}\right)$ and all versions of the application of soil conditioner PRP sol.

In the studied period, the highest total costs of soybean cultivation were achieved for variant application of HUMAC agro (variant $b_{3}$ ). It corresponds with the high-dosage $500 \mathrm{~kg} / \mathrm{ha}$ of this conditioner. The soil fertility stimulator would gradually release nutrients for a period of 4-5 years. Using conventional tillage $\left(a_{1}\right)$, the total cost of this option exceeded $€ 1000 / \mathrm{ha}$ (€1015.86-€1027.29/ha). With minimum tillage (variant $\mathrm{a}_{2}$ ), the total costs decreased significantly to €905.62-€921.83/ha and for direct sowing $\left(a_{3}\right)$ fell below $€ 900 /$ ha $(€ 871.20-€ 887.81 / h a)$. The option with the application of NPK alone $\left(b_{1}\right)$ had costs under $€ 787.29 / \mathrm{ha}$ at $\mathrm{a}_{1}$, under $€ 681.83 / \mathrm{ha}$ at $\mathrm{a}_{2}$ and under $€ 647.81 /$ ha at $\mathrm{a}_{3}$.

\section{Evaluation of economic indicators}

The economic indicators per hectare of soybean cultivation are assessed in Tables 4-6. Differences

T a b 1 e 4

Economy of soybean growing in 2010

\begin{tabular}{|c|c|c|c|c|c|c|c|c|c|c|}
\hline \multirow{2}{*}{ Parameter } & \multirow{2}{*}{$\begin{array}{c}\text { Unit of } \\
\text { measure }\end{array}$} & \multicolumn{3}{|c|}{$\mathrm{b}_{1}$} & \multicolumn{3}{|c|}{$\mathrm{b}_{2}$} & \multicolumn{3}{|c|}{$\mathrm{b}_{3}$} \\
\hline & & $\mathrm{a}_{1}$ & $\mathrm{a}_{2}$ & $\mathrm{a}_{3}$ & $a_{1}$ & $\mathrm{a}_{2}$ & $\mathrm{a}_{3}$ & $\mathrm{a}_{1}$ & $\mathrm{a}_{2}$ & $a_{3}$ \\
\hline Total production ${ }^{*}$ & {$[€ /$ ha $]$} & $1,452.00$ & $1,468.50$ & $1,303.50$ & $1,316.70$ & $1,428.90$ & $1,419.00$ & $1,567.50$ & $1,534.50$ & $1,224.30$ \\
\hline Economy result & {$[€ /$ ha $]$} & 660.18 & 802.88 & 655.69 & 432.90 & 671.30 & 679.21 & 535.68 & 628.88 & 336.49 \\
\hline Profitability per ha & {$[\%]$} & 83.38 & 120.62 & 101.22 & 48.98 & 88.61 & 91.81 & 51.92 & 69.44 & 37.90 \\
\hline Income threshold for zero profitability & {$[\mathrm{t} / \mathrm{ha}]$} & 2.40 & 2.02 & 1.96 & 2.68 & 2.30 & 2.24 & 3.13 & 2.74 & 2.69 \\
\hline
\end{tabular}

*Exercise price of production: 330.- $€ / \mathrm{t}$

Abbreviations see Table 1

T a

Economy of soybean growing in 2011

\begin{tabular}{|l|c|r|r|c|r|c|r|r|r|r|}
\hline \multirow{2}{*}{ Parameter } & \multirow{2}{*}{$\begin{array}{c}\text { Unit of } \\
\text { measure }\end{array}$} & \multicolumn{1}{c|}{$\mathrm{b}_{1}$} & \multicolumn{1}{c|}{$\mathrm{a}_{2}$} & \multicolumn{1}{c|}{$\mathrm{a}_{3}$} & \multicolumn{1}{c|}{$\mathrm{a}_{1}$} & \multicolumn{1}{c|}{$\mathrm{a}_{2}$} & \multicolumn{1}{c|}{$\mathrm{a}_{3}$} & \multicolumn{1}{c|}{$\mathrm{a}_{1}$} & \multicolumn{1}{c|}{$\mathrm{a}_{2}$} & \multicolumn{1}{c|}{$\mathrm{a}_{3}$} \\
\hline Total production $^{*}$ & {$[€ / \mathrm{ha}]$} & $1,662.00$ & $1,407.00$ & $1,371.00$ & $1,392.00$ & $1,413.00$ & $1,449.00$ & $1,494.00$ & $1,536.00$ & $1,386.00$ \\
Economy result & {$[€ / \mathrm{ha}]$} & 886.14 & 725.17 & 737.40 & 528.62 & 643.65 & 727.88 & 478.14 & 614.17 & 512.40 \\
Profitability per ha & {$[\%]$} & 114.21 & 106.35 & 116.38 & 61.23 & 83.66 & 100.94 & 47.07 & 66.62 & 58.65 \\
Income threshold for zero profitability & {$[\mathrm{t} / \mathrm{ha}]$} & 2.59 & 2.27 & 2.11 & 2.88 & 2.56 & 2.40 & 3.39 & 3.07 & 2.91 \\
\hline
\end{tabular}

*Exercise price of production: $300 .-€ / \mathrm{t}$

Abbreviations see Table 1 
T

Economy of soybean growing in 2012

\begin{tabular}{|c|c|c|c|c|c|c|c|c|c|c|}
\hline \multirow{2}{*}{ Parameter } & \multirow{2}{*}{$\begin{array}{c}\text { Unit of } \\
\text { measure }\end{array}$} & \multicolumn{3}{|c|}{$\mathrm{b}_{1}$} & \multicolumn{3}{|c|}{$\mathrm{b}_{2}$} & \multicolumn{3}{|c|}{$\mathrm{b}_{3}$} \\
\hline & & $a_{1}$ & $\mathrm{a}_{2}$ & $\mathrm{a}_{3}$ & $a_{1}$ & $\mathrm{a}_{2}$ & $\mathrm{a}_{3}$ & $a_{1}$ & $\mathrm{a}_{2}$ & $\mathrm{a}_{3}$ \\
\hline Total production* & {$[€ /$ ha $]$} & $1,972.00$ & $2,010.25$ & $1,241.00$ & $1,725.50$ & $02,031.50$ & $1,423.75$ & $1,763.75$ & $1,891.25$ & $1,508.75$ \\
\hline Economy result & {$[€ /$ ha $]$} & $1,184.71$ & $1,329.22$ & 609.80 & 833.80 & $01,246.06$ & 688.14 & 736.46 & 970.22 & 637.55 \\
\hline Profitability per ha & {$[\%]$} & 150.48 & 195.18 & 96.61 & 93.51 & 158.64 & 93.55 & 71.69 & 105.34 & 73.18 \\
\hline Income threshold for zero profitability & {$[\mathrm{t} / \mathrm{ha}]$} & 1.85 & 1.60 & 1.49 & 2.10 & 1.85 & 1.73 & 2.42 & 2.17 & 2.05 \\
\hline
\end{tabular}

*Exercise price of production: $425 .-€ / \mathrm{t}$

Abbreviations see Table 1

in overall production in each year were significantly affected by realisation price, which especially in 2012 has grown enormously to $€ 425 / \mathrm{t}$. Compared with 2010 , the increase was $€ 95 / \mathrm{t}$ and compared with $2011 € 125 /$ t. The significant differences between the prices at soybean marketing are pointed out by Vyn (2012). His findings highlight the risks that this entails for soybean growers. Marketing strategies for long-term monitoring showed lower net prices after crop harvesting. Katsvairo and Cox (2000) and Stanger et al. (2006) state that annually changing realisation prices and production costs as major risk factors are critical for evaluations of the economy in soybeans. They found the experiments were profitable, when soybean was cultivated in crop rotation with corn, using all tillage and maximal fertilisation.

High yields on experimental variations meant that during the whole experimental period the total production per hectare falls below $€ 1200 / \mathrm{ha}$. In 2010 (Table 4), production per hectare ranged from $€ 1224.30 /$ ha to $€ 1567.50 /$ ha. For each variant, a profit was achieved. The highest profit $€ 802.88 / \mathrm{ha}$ was achieved at minimum tillage variant with application of NPK alone (variant $b_{1}$ ), before direct sowing and minimum tillage variant $b_{2}$ applying conditioner PRP sol ( $€ 679.21 /$ ha and $€ 671.30 /$ ha, respectively). The variant of direct sowing in the application of soil fertility stimulator HUMAC agro (variant $b_{3}$ ) was the least profitable at $€ 336.49 /$ ha. The lowest profitability per hectare at $37.90 \%$ was in this variant. In the previous section, soybean yield parameters were evaluated. Based on statisti- cal evaluation between conventional tillage technology and minimum tillage, grain yield was not significantly different, indicating an advantage of this technology. Using the minimisation with the fertilisation variant $b_{1}$ in 2010, a sufficient yield to get a profit was higher than $2.02 \mathrm{t} / \mathrm{ha}$. The variant $\mathrm{b}_{2}$ (PRP sol) needs to achieve a yield higher than $2.30 \mathrm{t} / \mathrm{ha}$ and the $b_{3}$ variant (HUMAC agro) higher than $2.74 \mathrm{t} / \mathrm{ha}$.

In 2011 (Table 5), the high profit gain was also seen in all variants of experiment variations. When applying NPK (variant $b_{1}$ ), the highest profit $€ 886.14 /$ ha was achieved at conventional tillage. When applying conditioner PRP sol $\left(b_{2}\right)$, the direct sowing was most profitable at $€ 727.88 / \mathrm{ha}$ and in the application of HUMAC agro $\left(b_{3}\right)$, it was minimum tillage at $€ 614.17 / \mathrm{ha}$. The highest profitability per hectare was calculated for $b_{1}$ variants of fertilisation $(154.62 \%-161.36 \%)$, then $b_{2}$ variants $(61.23 \%-$ $100.94 \%)$ and finally $b_{3}$ variants $(47.07 \%-66.62 \%)$. Mainly due to lower exercise price of $€ 300 / t$, the income threshold for zero profitability was higher for all variants, compared with 2010. It follows that the higher yield is necessary to achieve profitable soybean cultivation.

Using minimum and conventional tillage technology, the highest total production was reached in 2012 (Table 6). Simultaneously, these tillage variants in 2012 were more profitable than in 2010 and 2011. In 2012, in all variants of fertilisation, the highest profit was achieved at minimum technology $\left(b_{1}-€ 1329.22 / h a, b_{2}-€ 1246.06 /\right.$ ha and $\left.b_{3}-€ 970.22 / h a\right)$. The direct sowing was the least 
profitable $\left(b_{1}-€ 609.80 / h a, b_{2}-€ 688.14 /\right.$ ha and $\left.b_{3}-€ 637.55 / \mathrm{ha}\right)$. In 2012 , the profitability per hectare of the experiment was $195.18 \%$ at $b_{1}$ fertilisation with minimum tillage. At a higher realisation price of $€ 425 / t$, the lowest income threshold for zero profitability was calculated in 2012 . Using the minimal tillage and the fertilisation variant $b_{1}$ in 2012, the sufficient yield to get the profit was higher than $1.60 \mathrm{t} / \mathrm{ha}$, for the variant $\mathrm{b}_{2}$ (PRP sol) it was necessary to achieve a yield higher than $1.85 \mathrm{t} / \mathrm{ha}$ and for the variant $b_{3}$ (HUMAC agro) it was higher than $2.17 \mathrm{t} / \mathrm{ha}$.

\section{CONCLUSIONS}

From the results of experiments with soybean in the years 2010-2012 the following conclusions can be formulated.

The weather events during the year significantly affected soybean grain yield. There were statistically significant differences in yields from the highest average yield for 2011 to 2010 and 2012 . Differentiated application of soil conditioners and fertilisers non-significantly influenced soybean grain yield. Statistically significantly higher yields were achieved at conventional and minimum tillage variant. For direct sowing variants, the grain yield of soybean was significantly lower.

The total costs of soybean crop management in comparison years have not changed significantly. The highest costs were at variants of fertilisation (with the application HUMAC agro + NPK). The lowest costs were at variants of fertilisation (with the application NPK alone). When comparing variants of tillage, significantly highest costs were at conventional variant each year. Significant savings occurred at minimum and direct sowing variants.

The exercise price of grain significantly affected the differences in total production for each year, which was the highest in $2012(€ 425 / \mathrm{t})$ and the lowest in $2011(€ 300 / \mathrm{t})$.

Using applied NPK alone, the highest profit in the years 2010 and 2012 was achieved at minimum tillage ( $€ 802.88 /$ ha and $€ 1329.22 / \mathrm{ha}$, respectively) and in 2011 at conventional variant (€886.16/ha). On a variant with PRP sol, the most profitable was direct sowing between 2010 and 2011 (€679.21/ha and $€ 727.88$ /ha, respectively), and in 2012 at minimisation of $€ 1246.06 /$ ha. Variant with HUMAC agro was the most profitable each year at minimum tillage. In 2010 , the profit was $€ 628.88 / \mathrm{ha}$, in 2011 it was $€ 614.17 / \mathrm{ha}$ and in 2012 it was $€ 970.22 / \mathrm{ha}$.

The highest profitability per hectare was achieved in the experiment in 2012.

The lowest income threshold for zero profitability was detected in 2012 when there was the largest grain price.

\section{REFERENCES}

ABRHAM, Z. - KOVÁŘOVÁ, M. - KOCÁNOVÁ, V. - HEROUT, M. - SCHEUFLER, V. 2007. Technické a technologické normativy pro zemédělskou výrobu [Technical and technological norms for agricultural production]. Praha: VUZT, no. 5, 29 p. ISBN 97886884-26-4.

ANTHONY, P. - MALZER, G. - SPARROW, S. - ZHANG, M. 2012. Soybean yield and quality in relation to soil properties. In Agronomy Journal, vol. 104, no. 5, pp. $1443-1458$.

ARCHER, D.W. - REICOSKY, D.C. 2008. Economic performance of alternative tillage systems in the Northern Corn Belt. In Agronomy Journal, vol. 101, no. 2, pp. 296-304.

BAllA, P. - HeCL, J. - KOTOROVÁ, D. - KOVÁČ, L. - ŠOLTYSOVA, B. 2012. Vplyv spôsobov využívania pôdy na kolobeh živín na t’ažkých pôdach [Effect of soil utilization modes on the mater circulation in Gleyic Luvisol]. In Hadházy - Henzsel: Examination of the effect of land utilization systems on water-and nutrient circulation of soils. Debrecen, pp. 26-45. ISBN 978-963-473-594-6.

BOTTA, G.F. - POZZOLO, O. - BOMBEN, M. ROSATTO, H. - RIVERO, D. - RESSIA, M. TOURN, M. - SOZA, E. - VAZQUEZ, J. 2007. Traffic alternatives for harvesting soybean (Glycine max L.): Effect on yields and soil under a direct sowing system. In Soil and Tillage Research, vol. 96, no. 1-2, pp. $145-154$.

DUSEJA, D.R. - DENNIS, S. 2010. Long-term effects of two tillage systems on soybean (Glycine max (L.) Merrill) (var. Forrest) production, soil properties and plant nutrient uptake. In 19th World Congress of Soil Science, Soil Solutions for a Changing World. Brisbane, Australia. Published on DVD.

FECÁK, P. - ŠARIKOVÁ, D. - ČERNÝ, I. 2009. Formation of soybean yields in dependence on conventional and reduce system of soil tillage. In Acta fytotechnica et zootechnica, vol. 12, no. 1, pp. 24-28.

FECÁK, P. - ŠARIKOVÁ, D. - ČERNÝ, I. 2010. Influence of tillage system and starting $\mathrm{N}$ fertilization on seed yield and quality of soybean Glycine max 
(L.) Merrill. In Plant, Soil and Environment, vol. 56 no. 3, pp. 105-110

GROFÍK, R. - FLAK, P. 1990. Statistical methods for agriculture. 1. ed. Bratislava : Príroda, 344 pp. ISBN 80-07-00018-6.

KATSVAIRO, T.W. - COX, W.J. 2000. Economics of Cropping Systems Featuring Different Rotations, Tillage, and Management. In Agronomy Journal, vol.92, no. 3, pp. 485-493.

KAVKA, M. 2006. Normativy zemédělských výrobnich technologii [Limits of agricultural production technologies]. Praha: ÚZPI, 376 p. ISBN 80-7271-164-4 .

KOTOROVÁ, D. 2012. Vplyv pôdnych stimulátorov na fyzikálne vlastnosti t'ažkých pôd [The effect of soil amendments on physical properties of heavy soils]. In Využivanie pôd v prihraničnej oblasti SlovenskoMad'arsko [Use of land in the border region SlovakiaHungary] : proceedings of scientific conference with international participation in the project of cross-border cooperation]. Michalovce : PPRC Research Institute of Agroecology, pp. 22-27. ISBN 978-80-89417.

LANÇA RODRÍGUES, J.G. - GAMERO, C.A. - COSTA FERNANDES, J. - MIRÁS-AVALOS, J. M. 2009. Effects of different soil tillage systems and coverages on soybean crop in the Botucatu Region in Brazil. In Spanish Journal Agricultural Research, vol. 7, no. 1, pp. 173-180.

POLÁČKOVÁ, J. - BOUDNÝ, J. - JANOTOVÁ, B. - NOVÁK, J. 2010. Metodika kalkulací nákladi̊ a výnosů v zemédèlství [Methodics for costing of costs and returns in agriculture]. Praha: ÚZEI, 58 p. ISBN 978-80-86671-75-8.

ROZBORILOVÁ, E. 2012. Definitivne údaje o úrode pol'nohospodárskych plodin a zeleniny $v$ SR za rok 2011 [Final data on crops and vegetables in the Slovak Republic in 2011]. Statistical Office of the Slovak Republic. 26 p. ISBN 978-80-8121-162-1.

STANGER, T.F. - LAUER, J.G. - CHAVAS, J.P. 2006. The profitability and risk of long-term cropping systems featuring different rotations and nitrogen rates. In Agronomy Journal, vol. 100, no. 1, pp. 105-113.
STATISTICAL OFFICE OF THE SLOVAK REPUBLIC. 2011. Definitívne údaje o úrode pol’nohospodárskych plodín a zeleniny v SR za rok 2010 [Final data on crops and vegetables in Slovakia in 2010]. Statistical Office of the Slovak Republic. 29 p. ISBN 978-808121-099-0.

ŠARIKOVÁ, D. - FECÁK, P. 2007. Vplyv hnojenia a obrábania pôdy na úrodu a kvalitu sóje fazul'ovej [Effect of different tillage and fertilization on soybean yield and seed quality]. In Zbornik vedeckých prác [Proceeding of scientific works] 23. Michalovce: SCPV - ÚA, pp. 161-169. ISBN 978-80-88872-70-2.

ŠOLTYSOVA, B. 2012. Vplyv aplikácie pôdneho kondicionéra na zmeny vybraných chemických vlastností t'ažkej fluvizeme glejovej [Effect of application of soil conditioner for changes selected chemical properties of heavy gleyic flivisol]. In Využivanie pôd $v$ prihraničnej oblasti Slovensko-Mad'arsko [Use of land in the border region Slovakia-Hungary] : proceedings of scientific conference with international participation in the project of cross-border cooperation. Michalovce : PPRC - Research Institute of Agroecology, pp. 34-41. ISBN 978-80-89417

TÓTH, Š. 2012. Úrodové výsledky realizátorského testovania prípravku HUMAC agro v pol’ných poloprevádzkových podmienkach [The HUMAC agro yield effect at field testing]. In Využivanie pôd $v$ prihraničnej oblasti Slovensko-Mad'arsko [Use of land in the border region Slovakia-Hungary] : proceedings of scientific conference with international participation in the project of cross-border cooperation). Michalovce : PPRC - Research Institute of Agroecology, pp. 42-49. ISBN 978-80-89417.

TRIPLETT, G.B. - DICK, W.A. 2007. No-Tillage crop production : A Revolution in agriculture! In Agronomy Journal, vol. 100, Supplement 3, pp. 153-165.

VYN, R.J. 2012. The effectiveness of alternative marketing strategies for Ontario corn and soybean producers. In Canadian Journal of Agricultural Economics/ Revue canadienne d'agroeconomie, vol. 60, no. 4, pp. 427-449.

Received: April 17, 2013 